International Journal of Linguistics, Literature and Translation

ISSN: 2617-0299 (Online); ISSN: 2708-0099 (Print)

DOI: $10.32996 / \mathrm{ijllt}$

Journal Homepage: www.al-kindipublisher.com/index.php/ijltt

IJLLT

\title{
Language-in-Education Policies in Malawi, Zambia and Rwanda as presented by Williams (2013): A Review
}

\author{
Edward Owusu ${ }^{1} \square$ Asuamah Adade-Yeboah², Solomon A. Dansieh ${ }^{3}$ and Charles Afram Snr ${ }^{4}$ \\ ${ }^{1}$ Senior Lecturer, Sunyani Technical University, Sunyani, Ghana \\ ${ }^{2}$ Senior Lecturer, Christian Service University College, Kumasi, Ghana \\ ${ }^{3}$ Senior Lecturer, Dr. Hilla Limann Technical University, Wa, Ghana \\ ${ }^{4}$ Lecturer, Sunyani Technical University, Sunyani, Ghana
}

$\square$ Corresponding Author: Edward Owusu, E-mail: edwardowusu@minister.com

\begin{tabular}{|c|c|}
\hline ARTICLE INFORMATION & ABSTRACT \\
\hline Received: 17 September 2021 & \multirow{7}{*}{$\begin{array}{l}\text { This paper reviews Williams' (2013) assessment of the language-in-education policies } \\
\text { of three African countries - Malawi, Zambia, and Rwanda. Williams' (2013) paper, } \\
\text { therefore, constitutes the main data of our review paper. The methodology used was } \\
\text { descriptive design. Specifically, content analysis was used in reviewing the main } \\
\text { sections of Williams' (2013) paper. The current paper has four sections. These are } \\
\text { introduction; language-in-education policies in Malawi, Zambia, and Rwanda; the } \\
\text { research design, findings, and conclusion of Williams (2013); and the conclusion. We } \\
\text { anticipate that the review would provide useful information for educationists, language } \\
\text { planning and policymakers, researchers, and all key stakeholders. }\end{array}$} \\
\hline Accepted: 14 October 2021 & \\
\hline Published: 31 October 2021 & \\
\hline DOI: 10.32996/ijllt.2021.4.10.28 & \\
\hline KEYWO & \\
\hline nguage & \\
\hline & \\
\hline
\end{tabular}

Indigenous Languages

\section{Introduction}

Language policies operate in some forms in all areas of society (Ricento, 2006). According to Kaplan and Baldauf (2003), though language planning and language policy are often used synonymously, they stand for divergent forms of activity, with language planning being the preliminary level which leads to the creation of language policy; and language policy being an extensive activity which includes language planning.

\subsection{Language Planning Defined}

Language planning has been defined by various writers and authorities in several ways. A classical definition by Cooper (1989, p. 45) sees language planning as "deliberate efforts to influence the behavior of others with respect to the acquisition, structure, or functional allocation of their language codes." The acquisition has to do with the efforts made to ensure that the language is extended to all potential users. The structure is the corpus planning which focuses on the nature of the language taught. The structure, thus, focuses on issues such as the writing of the language, the books that will contain the language, and grammatication of the language. Blommaert (1996, p. 207) extends the scope of language planning "to cover all cases in which authorities attempt, by whatever means, to shape a sociolinguistic profile for their society." Blommaert's (1996) definition covers issues such as authorities and sociolinguistics profile for their society. To him, it is an activity that is expected to be done by people in authority. Thus, language planning is not an individual affair but a decision taken by a government in power or those in positions of authority. Shaping the sociolinguistic profile for society is status planning. This is where issues such as officialization, nationalization, and proscription of the language are dealt with. At this level, the language for the media, and education, as well as regional languages, could be determined.

According to Herriman and Burnaby (1996), language planning is the factual realization of language policy. To the extent that policies are deliberately and consciously created, they usually involve some form of planning. This means that the policies could be centered on status, corpus, language-in-education, and prestige planning (Liddicoat, 2013, p. 2). At the language-in-education

Copyright: (c) 2021 the Author(s). This article is an open access article distributed under the terms and conditions of the Creative Commons Attribution (CC-BY) 4.0 license (https://creativecommons.org/licenses/by/4.0/). Published by Al-Kindi Centre for Research and Development, London, United Kingdom. 
planning level, policies such as access, personnel, lexication, graphization, and grammatication could be formulated. Liddicoat's (2013) definition has something in common with the two previous definitions from Cooper (1989) and Blommaert (1996). They have consciously or subconsciously made mention of status, corpus, prestige, and acquisition planning. To Kaplan and Baldauf (1997) language planning is a deliberate effort to influence the function, structure, or acquisition of languages or language varieties within a speech community. Kaplan and Baldauf's (1997) definition shares the same variables as those previously mentioned. Like the others (Cooper, 1989 and Blommaert, 1997), they consciously have mentioned the function and the structure or acquisition of languages. This is in direct consonance with Cooper (1989) but differs slightly from Blommaert (1997). Fishman (1987) also defined language planning as " the authoritative allocation of resources to the attainment of language status and corpus goals, whether in connection with new functions that are aspired to, or in connection with old functions that need to be discharged more adequately." Fishman's (1987) definition is in line with Blommaert's (1997). The two writers have mentioned the words - authorities and authoritative - in their definitions. This suggests that language planning is an activity done by people in authority. Coopers' (1989) definition uses the term or words deliberate efforts, and one could infer that these deliberate efforts are made by people in authority.

\subsection{Language Policy Defined}

Language policy involves the work of governments or people in authority and consists of the options made about languages and their connection to societal life (Liddicoat, 2013, p. 2). Djité (1994), as cited in Liddicoat (2013, p. 3), argues that language policy has to do with processes at two levels - societal and language. At the societal level, Djité (1994) has allocated these processes the identification of relevant problems, the formulation of alternatives to address these problems, and choosing from among these alternatives - to language policy. Thus, in coming out with a language policy for society, one has to first recognize the problem, generate alternative solutions for the problems, before selecting the best option out of the alternatives. Djité (1994), again, argues that "the language level involves processes of articulating linguistic norms which a community will use" (Liddicoat 2013:3).

\section{Language-in-Education Policies in Malawi, Zambia, and Rwanda.}

In Africa, almost all the countries are multilingual communities. Obviously, one factor that has accounted for this multilingualism is colonialism. After independence, African states added the language(s) of their colonial masters to their indigenous languages. Malawi and Zambia have a number of indigenous languages. While Malawi has 16, Zambia has as many as 43 (Lewis, 2009). In the two countries, Chichewa (Chewa), which is also known as Nyanja (Chinyanja), is the major language used in education. Therefore, on the borders of the two countries, the Chichewa/Nyanja language is spoken (Williams, 2013, p.70).

\subsection{The Case of Malawi}

In Malawi, their language policy for the eight years of primary education is that from years 1 to 4 , Chichewa is the medium of instruction; and during this time, English is taught as a subject. Apparently, this gives the young learner the opportunity to master their own first language (L1) before they are introduced to the second language (L2). When they get to the 5th year, English becomes the medium of instruction, and Chichewa is learned as a subject (Williams, 2013, p. 70). This system continues till the learner gets to the 8th year. Ostensibly, Malawi wants its folks to attain balanced bilingualism; hence, this language policy.

\subsection{The Case of Zambia}

The situation in Zambia is different. English is the medium of instruction for primary school years (that is from primary/year 1 to 7), and Chichewa and six other Zambian languages are expected to be taught as subjects at this level. This is done in theory, but in practice, they are not learned, as local languages are not used as a basis for promotion to the secondary school level (Williams, 2013 , p. 70 - 71). This practice, thus, kills the local languages and the learner's drive for his or her own mother tongue. It has the propensity of leading to subtractive bilingualism.

\subsection{The Case of Rwanda}

Unlike Malawi and Zambia, the language-in-education policy in Rwanda is entirely different. In Rwanda, the majority (about 99.4\%) of the inhabitants speak the same language - Kinyarwanda - and this makes them highly monolingual (Rosendal, 2009 as cited in Samuelson \& Freedman, 2010). According to LeClerc (2008) and Munyankesha (2004), about $90 \%$ of Rwandans speak only Kinyarwanda. After the 1994 massacres that claimed many lives, Kinyarwanda was used as the solitary means of education at the primary stage; and French was used as the medium of education from secondary school upwards (Williams, 2013). This decision was possible because the majority of Rwandans speak Kinyarwanda. So, having this language, Kinyarwanda, as the only medium of instruction at the primary level was not intricate. A problem could have arisen if $50 \%$ or less of the people were speaking this L1. Unfortunately, Williams' (2013) report did not tell us of the number of years a child spends at the primary level. Truly, if the only medium of instruction used for the learner's 6 or 7 years of primary education is the L1, the learner may struggle in acquiring or learning a second or a third language at the secondary level; (especially when he or she has grown past the formative years). However, if the learner learns a second or a third language at the primary school level as a subject, this challenge could be 
minimized. In 2009, the Tutsi-dominated government, who are large 'Anglophone', instituted English as the medium of instruction from the beginning of primary onwards (Williams, 2013). The rationale behind this policy was to raise a generation of Rwandans who are fluent in the English language. The number one challenge was the English language schooling of the thousands of teachers who have previously used only French and Kinyarwanda as the medium of instruction (Williams, 2013). This policy was too harsh. In piecemeal, English could have been introduced as a subject learned in class. This could have at least given the learners a certain level of proficiency in English before it was used as the medium of instruction.

However, in 2011, there was a further change of language policy when it was announced by the Minister of Primary and Secondary Education that the medium of instruction for the first three years of primary school would be Kinyarwanda, with English and French taught as subjects (The New Times, 2011 as cited in Williams, 2013). This policy is commendable. Asking a learner to use his or her first mother tongue at the initial stages of his or her education would enable him or her to better understand the second language as soon as he or she is introduced to it.

\subsection{The Teaching and Learning of English in the Classrooms of Malawi, Zambia, and Rwanda}

Williams (2013) conducted longitudinal research about English language teaching in some primary schools in Malawi, Zambia, and Rwanda. This observational study of over 100 lessons was conducted in each of the three countries from 1992 to 2004. The findings of the research brought to light that the three countries share a similar style of teaching and learning English. For example, learners were drilled on some new vocabulary items at the onset of reading comprehension sessions. Sometimes, the teacher used words from pictures in drilling the students. After the drilling process, the teacher or students took turns in reading the whole text aloud. When the text is read, students repeat it after the teacher or whoever is leading the class. After this phase, the teacher asked direct oral reference questions. Sometimes, the students are assessed on the task they performed in class. They do so by solving some written questions in their books.

\section{The Research Design, Findings and Conclusion of Williams (2013) 3.1 The Research Design}

The research involved an investigation of reading proficiency in Malawi, Zambia, and Rwanda. The method used to collect data was a discussion on reading tests. The research activities for Malawi and Zambia were carried out from 1992 to 1996 . However, for Rwanda, the research was conducted from 2003 to 2004 (Williams, 2013, p. 74). Thirty (30) cloze test items per test of reading in English and Chichewa were used in Malawi and Zambia. The tests were done in Chichewa-speaking communities of the two countries - Malawi and Zambia (Williams, 2013, p. 74). Year 5 students were used as the participants since it was the year that schools in Malawi switched to English as a medium. Again, the participants were drawn from two urban schools and four rural schools. Two hundred and ninety (290) pupils constituted the sample size for the participants from Malawi while 227 pupils were sampled from Zambia (Williams, 2013, p. 74). In Rwanda, the research conducted in 2003 involved an investigation into students' proficiency in English, French, and Kinyarwanda in six primary schools (Williams, 2013, p. 75). The participants were drawn from four rural and two urban schools. The modified cloze format tests were employed and administered at Year 4 although they were based on material taken from the Years $1-3$ (Williams, 2013, p. 75). The participants that constituted the sample size were 261 primary school students. They were tested in all three languages spoken in Rwanda - English, French, and Kinyarwanda (Williams, 2013, p. 75).

\subsection{The Findings}

From Malawi and Zambia, the study revealed that there is no disparity in English language reading aptitude between the school children from the two countries at Year 5 (Williams, 2013, p. 74). Two, the study brought to light that Year 5 Zambian children (who officially had their first four years of education through the medium of English) are not superior to Malawian children who have had Chichewa as a medium of instruction for those years (Williams, 2013, p. 74. This situation confirms research works about the superiority of first languages in the performance of the second language learner (Owusu, et. al 2015; Anyidoho, 2009). One would have expected the Zambian children to outperform the Malawian children since the former had had prior exposure to the English language. But, this is not so. This presupposes that one is able to learn and perform well if one is exposed to one's first language at a tender age. Furthermore, the results from the two countries revealed that students' English levels are not enough for learning completely through the medium of English. That really proves that the language-in-education policy for the two countries - Malawi and Zambia - at the primary level needs revision.

Again, the analysis of the results for Malawi also brought to light that "Chichewa discriminates far less than English against rural children, the possible basis being that urban children are more likely to come across English in their everyday environments than rural children (Williams, 2013, p. 75)". Thus, when an L1 (which is known by the students) is used for learning, students perform better than using a second language. This proves that it would be unsafe to use a second language in assessing pupils when they 
have already gained a certain level of competence in a first language. The $L 2$ can be used when a certain level of bilingualism (for example, balanced bilingualism) has been attained by the students.

In the case of Rwanda, it was revealed that proficiency in English was extremely weak. While proficiency in French was fair, it was strong in Kinyarwanda (Williams, 2013, p. 75). Judging from this revelation, it is clear that Rwandan students perform better in Kinyarwanda than in any other second language. By inference, most students would read and write better in Kinyarwanda than in English or in French. Therefore, in such a country, it will not be the best to coerce learners to study all subjects in English or in French. If performance and knowledge are the two variables that educational authorities want, then learners should not be forced to study all subjects in English or in any other second language. For example, if we want learners to gain some scientific knowledge, we could use an L1 that learners are conversant with. By that, learners would understand concepts well.

\subsection{The Conclusion of Williams (2013)}

The overall conclusion of Williams (2013) is that English language aptitude is tremendously poor in the primary schools of the three countries studied - Zambia, Malawi, and Rwanda. Therefore, most of the pupils are not in a position to read their textbooks for either English or other curriculum subjects (Williams, 2013, p. 76). This conclusion confirms the position of some researchers about the need to use first languages in teaching the Africa child at the basic level (for example, Owusu, et. al 2015; Anyidoho, 2009). Consequently, there has been a series of pronouncements about the need to use African languages in educating African students. Some of these declarations are:

- $\quad$ 1909: United Missionary Conference, Kenya

- 1922: The Phelps-Stokes Commission of West Africa

- 1953: UNESCO Report on the Use of the Vernacular Languages in Education

- 1976: Lagos Conference of Education Ministries of African Member States

- 1982: Harare Declaration of Ministers of Education of African Member States

- 1986: OAU's Language Plan of Action for Africa

- 1994: Pan African Colloquium on Educational Innovation in Post-Colonial Africa

- 1997: Intergovernmental Conference of African Language Policies in Africa

- 2010: African Conference on Integration of African Languages and Cultures into Education, Burkina Faso.

Source: Williams $(2013$, p.77)

However, such pronouncements have been seriously looked down upon by some present and past African governments. Ironically, most African governments, over the years, have accepted language policies that mostly have English or French as the medium of instruction (MOI). This has not been fruitful. But, one wonders why they still pursue such unproductive language policies. Could it be a policy from donor countries and agencies? According to Williams (2013), they do that because of two obvious reasons - for unification and development.

\subsubsection{Language Policies for National Unification}

In Zambia, English was to serve an important role in the amalgamation of the black and white societies after the nation's independence. National language was, therefore, made mention of. Ironically, this national language was English and not any local language. Here, the inference is that policymakers probably thought that using the language of the colonial master would succeed in making unifying Zambians. Thus, their own first languages were relegated to the background.

Nevertheless, in Malawi, English was not regarded as the sole linguistic means of unification. From 1969, it was the indigenous Chichewa that was imposed by President Banda as the $\mathrm{MOI}$ in the first four years of primary education. This was intended to create national unity (Kayambazinthu, 1999). Indeed, this was a good idea, but it was not comprehensive. It was at the primary level only. Thus, at the upper levels of state institutions, English was intended to play a communicatively unifying role. Therefore, English was made compulsory, especially in the formal sectors like the parliament; and all MPs were required to pass a stringent test in it (Schmied, 1991).

In Rwanda, the case was slightly different. Since approximately the whole population was fluent in Kinyarwanda, the use of any other language to serve the purpose of unification was not needed. English was rather used for political alignment (Macintyre, 2010). Thus, in Rwanda, Kinyarwanda was the indigenous language used in unifying the masses. 


\subsubsection{Language Policies for National Development}

Development is a complex concept to define. If we are to use economic pointers such as mortality rate, poverty, growth rate, population, diseases, and educational advancement, it is obvious that Malawi, Zambia, and Rwanda may be marginally disadvantaged as compared to situations pertaining to most advanced countries. Nevertheless, if we are to consider development from a language policy point of view, then you realize that the three countries are doing their possible best to ensure that English (which is widely considered as the number one language in the world) is given the needed attention. The three counties have thought of English as a medium that can help promote trade and investments in their developing countries. English, thus, has the propensity of attracting foreign investors, which can lead to national development.

\section{Conclusion}

In nation-building, language planning and language policies are two multifarious issues that confront most multi-lingual African countries. Because multi-lingual communities have several first languages, there is always the need for them to develop clear-cut policy documents on language. Thus, language and language planning and policy issues are instrumental in building every nation. This current paper, therefore, reviewed Williams' (2013) research work on Language-in-Education Policies in Malawi, Zambia, and Rwanda. The contribution of knowledge of this review paper is positioned in the constructive critique of the main tenets of William (2013); and the position of the authors about the use of indigenous languages in multilingual classroom settings. It is important to note that in as much as developing countries (mostly African nations) need to have indigenous languages as official languages (because of their ability to create an identity); it is equally important to have languages that have the propensity of attracting investors for nation-building.

\section{References}

[1] Anyidoho, L. A. (2009). First Language in the Education of Children Multi-Lingual Ghana. New Legon Observer, 3 (1),11.

[2] Blommaert, J. (1996). Language planning as a discourse on language and society: The linguistic ideology of a scholarly tradition. Language Problems and Language Planning, 20 (3), 199-222.

[3] Cooper, R. L. (1989). Language Planning and Social Change. Cambridge University Press.

[4] Djité, P. (1994). From Language Policy to Language Planning. National Languages and Literacy Institute of Australia.

[5] Fishman, J. A. (1987). "Conference Comments: Reflections on the Current State of Language Planning". In Proceedings of the International Colloquiumon Language Planning, L. Laforge (presentation), 405-428. University of Laval Press

[6] Herriman, M., \& Burnaby, B. (1996). Language Policies in English-dominant countries. Multilingual Matters.

[7] Kaplan, R. B. \& Baldauf, R. B.,. (1997). Language Planning: from Practice to Theory. Multilingual Matters.

[8] Kaplan, K. \& Bladauf, R. B. (2003). Language and Language-in-Education Planning in the Pacific Basin. Kluwer.

[9] Kayambazinthu, E. (1999). The Language Planning Situation in Malawi. In b. Kaplan and R. B. Baldauf (eds.) Language Planning in Malawi, Mozambique and the Philippines, 15-85. Multilingual Matters

[10] LeClerc, J. (2008). Rwanda L'aménagement Linguistique dans Lemonade. http://www.tlfq.ca/axl/afrique/rwanda.htm

[11] Lewis, M. P. (2009). Ethnologue: Languages of the World, 16th Edition. SIL International. http://www.ethnologue.com

[12] Liddicoat, A. R. (2013). Language-in-Education Policies: The Discursive Construction of Intercultural Relations. Multilingual Matters

[13] Macintyre, J. (2010). Charity must not stop at home. New Statesman. www.newstatesman.com/international-politics/2010/08/mitchelldevelopment-aid

[14] Munyankesha, P. (2004). Les Defis du Plurilinguisme Official au Rwanda. Analyse sociolinguistique. [Ph.D. thesis], The University of Western Ontario.

[15] Owusu, E., Agor, J. \& Amuzu, K. E. (2015). Second Language Learners' Family Background and Their English Writing Competence: The Case of a Private Tertiary Institution in Ghana. Studies in English Language Teaching, 3(4), 466-486

[16] Owusu-Ansah, D. (2009). The People of Ghana: Ethnic Groups and Languages. Microsoft ${ }^{\circledR}$ Student 2009 [DVD]. Microsoft Corporation, 2008.

[17] Ricento, T. (2006). Language Policy: Theory and Practice- an Introduction. In T. Ricento (ed.) An Introduction to Language Policy: Theory and Method,10-23.

[18] Rosendal, T. (2009). Linguistic markets in Rwanda: Language use in advertisements and on signs. Journal of Multilingual and Multicultural Development 30(1), 19-39

[19] Samuelson, B. L. \& Freedman S. W. (2010). Language Policy, Multilingual Education, and Power in Rwanda. Language Policy 9, $191-215$.

[20] Schmied, J. (1991). English in Africa. Longman

[21] Williams, E. (2013). Political Perspectives on Language Policies and Development in Africa. In Elizabeth, J. Erling \& Philip, Seargeant (eds.), English and Development: Policy, Pedagogy and Globalization, 68 - 87. Multilingual Matters 